\title{
HUIDIGE INVLOED EN VOORUITSIGTE VAN OPVOEDKUNDIGE TEGNOLOGIE
}

Maj U. Bouwer*

\begin{abstract}
Educational Technology is destined to emerge as the great central humane discipline of the future. This hypothesis is formulated by the author. In the article she presents a brief review of the development in Educational Technology with special reference to the system approach and its influence on the military training sphere.
\end{abstract}

\section{Inleiding}

Volgens die skeppingsverhaal het God die hemel en aarde asook die mens gemaak en die mens toe ingelig oor hoe om op hierdie aarde te lewe: 'Jy mag van al die vrugte in die tuin eet' (Gen 2:16). Miljoene jare later het die tegnologie die mens geleer om 'n 'nuwe' wêreld te 'maak'. Die maan is reeds bereik, siektes en ouderdom word in 'n groot mate beheer en kommunikasie is moontlik deur middel van die radio, teleks, telefoon, televisie en satelliete $(4: 166)$ - maar nou moet die mens ook leer om in hierdie 'nuwe' wêreld te lewe. Slaughter (32:46) sê dat: '. . .technological change inevitably leads to social change ... and social changes demand for a more relevant education.' Dit moet dus gaan om relevante leerteorieë, onderwysmetodes, kurrikula, organisasie en administrasie, omdat die gemeenskap 'n meer effektiewe gebruikswyse van bronnemateriaal soos talente en tyd eis $(4: 168)$

In hierdie artikel sal daar naas 'n kort geskiedkundige oorsig oor die ontwikkeling van Opvoedkundige Tegnologie waarin die begrip omskryf word, eerstens aandag gegee word aan die sisteembenadering as uitvloeisel daarvan. Voorts sal aangedui word wat die rol van Opvoedkundige Tegnologie in hierdie verband is, waarna die invloed in die militêre opleidingsfeer aandag sal geniet. 'n Kort toekomsblik word ten slotte gewaag.

\section{Ontwikkeling in Opvoedkundige Tegnologie}

\section{Inleiding}

$\mathrm{Na}$ die Tweede Wêreldoorlog, in die tydperk 1945-1966, vind 'n opbloei van die tegnologie plaas, met as gevolg 'n verhoogde aanvraag na produksie en dus noodwendig opleiding. Aangesien 'the age of gadgetry' aangebreek het, wen onderrigmasjiene en die gebruik van oudio- visuele media baie veld. Hierdie verbintenis bring egter weerstand, veral van diegene wat onderwys as 'n kuns sien (26:85). Dit moet egter uitgewys word dat die woord 'tegnologie' vanaf 1630 dateer toe van masjiene nog geen sprake was nie. 'This early usage of the word 'technology' was concerned with analyzing and synthesizing situations so that people could learn.'

Davis en Hartley (21:13-15) onderskei drie verskillende vorms van Opvoedkundige Tegnologie wat op verskillende benaderings van die woord 'tegnologie' gebaseer is.

- Opvoedkundige Tegnologie I. Die student is gesien as die passiewe komponent van die onderrig/leersituasie, wat van buite af gemanupileer kan word, deur middel van die gebruik van masjiene. Opvoedkundige Tegnologie is dus slegs die onderrighulpmiddel. Dit gaan slegs oor die toepassing van tegnologie in onderwys en opleiding (12:138, 53:160)

- Opvoedkundige Tegnologie 2. Met die ontwikkeling van die menswetenskappe vind 'n klemverskuiwing plaas. Aangesien nuwe kennis oor die mens se kognitiewe, affektiewe en psigomotoriese potensiaal ontsluit word, beklemtoon hierdie benadering die ontwerp en struktuur van leerbronne (materiaal) om aan te pas by die leerder (12:138).

- Opvoedkundige Tegnologie 3. In hierdie benadering gaan dit nie bloot oor die feit dat dinge reg gedoen moet word nie (truprojektor moet reg gebruik word nie), maar oor die doen van die regte dinge. Nunan (33:180) wys daarop dat die operatiewe (praktiese) sowel as die normatiewe (teorie om die praktyk te motiveer) veronderstel word. Opvoedkundige Tegnologie is dus ' $n$ mengsel van onderrig en tegnologie - 'how to teach' maar ook 'what is to be taught' (32:86).

Neville (31:10) onderskryf die Council for Educational Technology se definisie en sien Opvoedkundige Tegnologie as die toepassing van kennis, sisteme en tegnieke om leer by die mens te 
verbeter. Drie dinge het volgens Davies (7:4) tot hierdie siening bygedra. Eerstens het wetenskaplike ontwerp, evaluering, seleksie en toetsing moontlik geword as gevolg van die ontwikkelinge in wiskunde; tweedens het die ontwikkelinge in die menswetenskappe kennis in verband met individuele verskille, groepprosesse, leerteorieë en motivering verskaf; derdens het spesifieke tegnologieë soos geprogrammeerde onderrig, matelogie en bestuur 'n bydrae gelewer. Austwick (1:21) stel dit dan ook duidelik dat Opvoedkundige Tegnologie 'n toegepaste wetenskap is, want dit is 'n toepassing van baie wetenskappe soos byvoorbeeld sosiologie, sielkunde, beligting, struktuur, drukkuns, fotografie, akoestiek, elektronika, bestuur, argitektuur, boukunde, sisteemanalise en kommunikasie. Waar die wetenskap koud en objektief beskryf, meet en klassifiseer, het die tegnologie te doen met die toepassing van hierdie wetenskaplike gevolgtrekkings op die mens en die gemeenskap: 'Therefore technology is inseparable from humanism.' (45:232)

Volgens Slaughter (41:52): 'Educational Technology is not intended to dehumanize education. On the contrary, it will humanize education if it is used properly. It is not intended to cement educational practices. On the contrary, it will help bring about innovations. It is not intended to replace or in any way to diminish the importance of the teacher. On the contrary, it will help the teacher do a more creative job.'

Hierdie siening van Opvoedkundige Tegnologie as 'n toepassing van verskillende wetenskappe, bring mee dat besluite nie meer in afsondering geneem kan word nie; dat oor die volle implikasies besin moet word, met ander woorde '...you see things not as isolated entities' (1:22), maar as ' $n$ komplekse geheel en dit bring ons by die sisteembenadering tot onderwys en opleiding.

\section{Die Sisteembenadering in onderwys en opleiding}

\section{Inleiding}

Opvoedkundige Tegnologie laat ' $n$ mens besef dat onderwys en opleiding nie meer ' $n$ privaatverantwoordelikheid is nie; dat die breë opset van onderwys en opleiding 'n komponent (subsisteem) van die samelewing as geheel vorm (4:170). As sodanig is die sisteembenadering ' $n$ direkte uitvloeisel van Opvoedkundige Tegnolo- gie (4:169), want dit verskaf 'n raamwerk ('conceptual framework') of model waarvolgens onderwys en opleiding sistematies en wetenskaplik aangepak kan word. (40:268)

\section{Wat is 'n Sisteem?}

Volgens Hodge (22:72) is ' $n$ sisteem '.. any entity, conceptual or physical, that consists of independant but interrelated parts.' Dat ' $n$ sisteem 'n afgebakende grens het (38:12), word duidelik as na die menslike liggaam as sisteem gekyk word. Beide die bloedsomloop - en die spysverteringsisteme is sisteme binne hul onderskeie grense, maar wanneer die menslike liggaam as geheel as sisteem gesien word, word hierdie sisteme as subsisteme ingesluit. Die kibernetika (sisteemteorie) het dan ook as wetenskap voortgevloei uit die bestudering van sulke biologiese sisteme.

Beishon $(2: 15,19)$ onderskei onder andere oop en geslote sisteme. Waar die geslote sisteme geen interaksie met die omgewing toelaat nie en uiteindelik 'n staat van ekwilibrium bereik, laat die oop sisteem voortdurende interaksie (deur middel van insette en uitsette) met die omgewing toe, aanpassings kom in die struktuur van die sisteem voor en disorganisasie van die sisteem word verhoed.

Sisteme word dan ook heel dikwels met behulp van modelle (grafies, fisies, simbolies) voorgestel (22:80). Die volgende grafiese voorstelling van ' $n$ sisteem het nie verdere toeligting nodig nie.

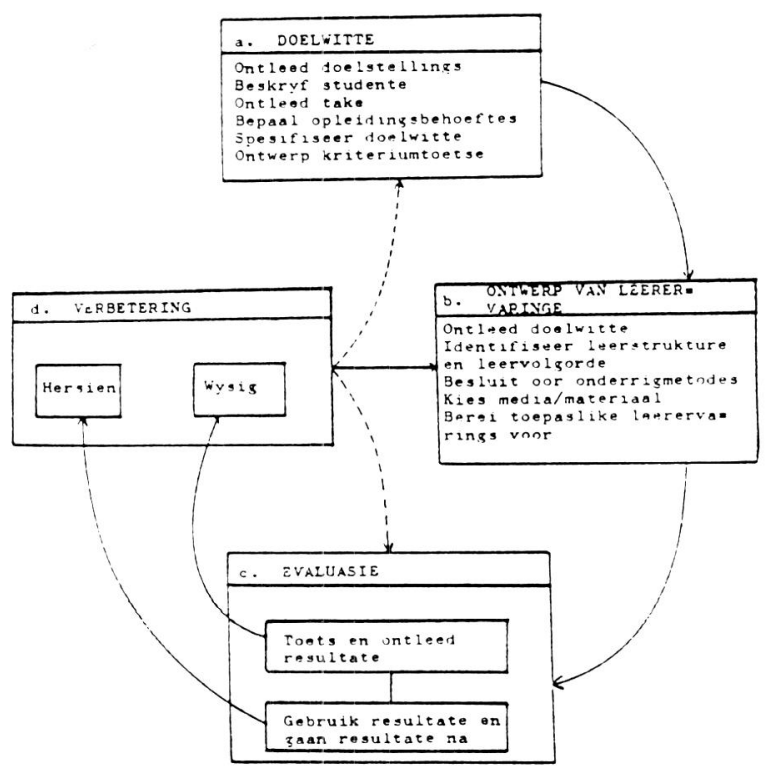


Die mens is ' $n$ sinsoeker by uitnemendheid en daarom kan deelsin hom nie meer tevrede stel nie; hy wil deelperspektiewe tot een geheel in 'n sisteem integreer. Dat die gebruik van 'n sisteembenadering meer as net sin bring, is in die Amerikaanse Weermag besef toe hulle hul antimissielsisteem gekoppel het met die vroeë waarskuwingsisteem, grondfasiliteite en operateurs en sodoende een geïntegreerde wapensisteem daargestel en groter effektiwiteit bewerkstellig het. (40:270)

\section{Die onderrigsisteem}

Om dieselfde effektiwiteit en sin in die onderwys en opleiding te probeer verkry, word dit ook as 'n sisteem benader. So gesien: 'The instructional system is a man-made system which has a dynamic interaction with its environment - teachers, learners, instructional resources, procedures, administrators, school board, parents, local community, government and many other agencies. Furthermore, the instructional system is a system of interrelated parts working in conjunction with each other in order to accomplish a number of goals' $(40: 272)$

Die onderrigsisteem het dus ontstaan uit die behoefte in ons snel veranderende wêreld om die beste metodes te vind om studente in die kortste moontlike tyd tot die hoogste moontlike standaard van doeltreffendheid op te lei. Hierdie benadering het dan ook veral by opleiding in die militêre sfeer groot waarde, aangesien effektiewe opleiding gemeet word aan die kwantiteit (hoeveel geleer is), kwaliteit (hoe goed geleer is) en tempo (hoe vinnig geleer is). 'n Onderrigsisteem impliseer dus ' $n$ doelgerigte proses van onderrig wat dan ook vooruit beplan is. Die eienskappe waaraan 'n onderrigsisteem uitgeken kan word, is die teenwoordigheid van doelwitte, asook voorafbeplanning en -evaluering om te bepaal of die doelwitte bereik is, al dan nie $(37: 4)$

Soos reeds gesien, bestaan sisteme nie in isolasie nie. Elke leersisteem bestaan ook in 'n verhouding tot ' $n$ ander sisteem. Hulle vorm elk 'n deel van 'n groter leersisteem, maar bestaan ook uit dele wat op sigself leersisteme is. Vergelyk byvoorbeeld die kursus as sisteem wat uit lesse bestaan wat op hul beurt sisteme is waarin verder die 'instructional event' en die 'learning step' onderskei kan word. (37:270) 'A learning system may (thus) be one student reading a book or an entire school or college' (8:303)

\section{Wat behels die fisiese toepassing van 'n sisteembenadering in onderwys en opleiding?}

'The term Systems Approach is used in so many contexts that it is difficult to assign a meaning that is not so general as to be virtually useless. Most authors agree however that the concept includes formal problem solving' (13:28). Daar is dan diegene wat die sisteembenadering sien as 'n wetenskaplike metode van probleemoplossing waar 'n probleem geïdentifiseer word, 'n hipotese gestel en dan geëvalueer word of die hipotese korrek bewys is (38:17). In Rowntree (17:1) se woorde: 'Apply a scientific method according to a system of logic in order to get the learner from where he is to where you want him to be.'

Ander skrywers lei weer hul interpretasie van die sisteembenadering af van die kibernetika (sisteemteorie) (46:279). Kibernetika verskaf volgens Smith (14:46) 'n teorie 'as useful in general teaching practice as a laboratory research.' In sodanige geval word daar vir die interafhanklikheid van die komponente in die sisteem voorsiening gemaak. 'If technology teaches us to specialize and science to analize the world into separate sections, cybernetics is showing us how all these bits and pieces can take their place in one vast communications network' (5:91). Alhoewel die teorie van onderrig en leer nooit met die kibernetika gelyk gestel kan word nie, is die ontleding van instruksionele prosesse in komponente (soos kibernetika voorstel) waardevol, want: :cybernetics can expose some significant shortcomings in instructional theory and practice and could ... integrate how these shortcomings might be eliminated' (25:4). Hierdie siening van die sisteembenadering maak dit moontlik om dit te sien as 'n bestuurshulpmiddel - ' [the term cybernetics] is descerned from the Greek meaning 'steersman' (14:46). 'He will need to regard his job not so much as 'teaching' but rather as 'arranging for learning to take place' ' (39:25), met ander woorde bestuurstegnieke (organisering, beplanning, leiding en kontrole) word toegepas om die beste verhouding tussen koste en effektiwiteit te verkry.

So gesien, beklee die instrukteur nie altyd dieselfde plek nie - hy is nie altyd slegs instrukteur in die tradisionele sin van die woord nie: 'He may be the designer of the system as well as one of the system elements, performing the traditional teaching function. The instructor as a system designer, would therefore design himself into the system to perform the teaching function' (7:305). 
As bestuurder van opleiding beklee hy nou die rol van beplanner, organiseerder, leier en beheerder van die leerverloop (6:141). As beplanner stel hy doelwitte na aanleiding van opleidingsbehoeftes; as organiseerder bepaal hy watter apparatuur, programmatuur, fasiliteite en mense benodig word; as leier motiveer, lei en begelei hy studente as individue en as beheerder evalueer hy of sukses behaal is. 'The application of cybernetic teaching devices does not displace the teacher from the instructional and learning process. It only alters his functions' (25:23). Die instrukteur se kreatiwiteit en inisiatief word dus nie onderdruk nie, maar word nie meer gebruik 'towards discovering independantly that which science has already discovered' (25:40).

\section{Verskillende stappe in (modelle van) die sisteembenadering}

Omdat die sisteembenadering 'n wetenskaplike benadering is, moet daar duidelike doelwitte wees (sodat 'n mens presies kan weet wat gedoen moet word), asook ' $n$ metode om te evalueer of die doelwitte bereik is. Verskillende skrywers onderskei hier verskillende stappe. Hodge (22:12) is byvoorbeeld van mening dat die komponente en die verhoudings tussen hulle eerstens geanaliseer moet word; sintese moet dan plaasvind waarin al die elemente weer gekombineer word (verouderde idees uitgeskakel en nuwe relevante elemente ingebring word), 'n model moet dan gekonstrueer word waarna die sisteem eers gesimuleer word alvorens dit op groot skaal geïmplementeer word. 'n Model dien dus as brug tussen teorie en praktyk.

Aangesien die sisteembenadering se grootste toepassingsmoontlikheid lê by die leerplanontwikkeling word Rowntree se model vir leerplanontwikkeling (soos aangepas vir die SA Weermag) hieronder gegee (24:16):

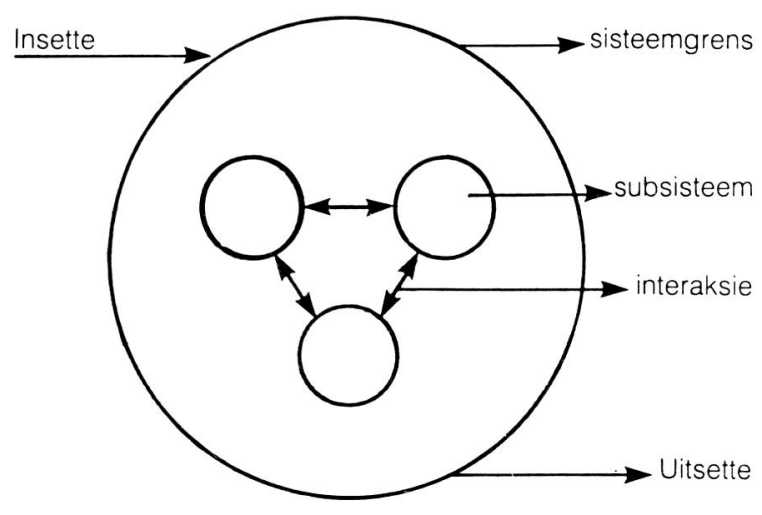

Alhoewel sommige modelle dit laat lyk asof die stappe sistematies op mekaar volg, maak voortdurende terugvoer ('feedback') 'cycling recirculating' moontlik (38:16). Neil (29:59) waarsku dan ook teen die gedagte om die sisteembenadering te sien bloot as ' $n$ sistematiese benadering met 'n definitiewe begin en einde - 'n sisteem het nie ' $n$ begin en einde nie.

\section{Gevolgtrekking}

Die sisteembenadering moet dus gesien word as 'particular method of exploration to find effective ways of talking about, designing and organizing learning situations in practice' (30:72) 'We are concerned solely with the ends and not with the means' (18:29) Eerder as om die alternatiewe en inisiatief van die instrukteur weg te neem, word sy oë oopgemaak om die verskeie moontlikhede in situasies raak te sien.

\section{Opvoedkundige Tegnologie in Tersiêre onderrigverband}

\section{Inleiding}

Aangesien die tersiêre onderrigveld alle onderwys en opleiding insluit wat op ná-sekondêre skoolvlak bedryf word, is universiteitsopleiding, opleiding aan tegniese kolleges, industriële opleiding, opleiding in die weermag, die polisie, ensovoorts hier ter sprake.

Die tersiêre onderrigsisteem vorm ' $n$ subsisteem van die onderrigsisteem wat weer 'n subsisteem van die samelewing as suprasisteem uitmaak (27:483). So gesien is dit duidelik dat die snelle ontwikkeling van die tegnologie met sy gevolge ook die sisteem van die onderrig sal beïnvloed en dat die tersiêre onderrig as verdere subsisteem nie aan hierdie invloed sal kan ontkom nie $(34: 149,150)$.

\section{Die waarde van Opvoedkundige Tegnologie in Tersiêre Onderrigverband}

Soos reeds gesien, slaan die term 'Opvoedkundige Tegnologie' nie op die blote gebruik van masjiene en hulpmiddels by onderrig en leer nie. Dit kan dus nie bloot as ' $n$ uitvloeisel van die tegnologiese era beskou word nie. Opvoedkundige Tegnologie, en daarmee saam die sisteembenadering, is egter die antwoord op die noodroep wat vanuit tersiêre onderriggeledere gehoor word. Vergelyk die volgende aangeleenthede: Baie kennis moet as gevolg van die 
kennisontploffing aan groot getalle studente oorgedra word - Opvoedkundige Tegnologie onderskryf die gebruik van gesofistikeerde

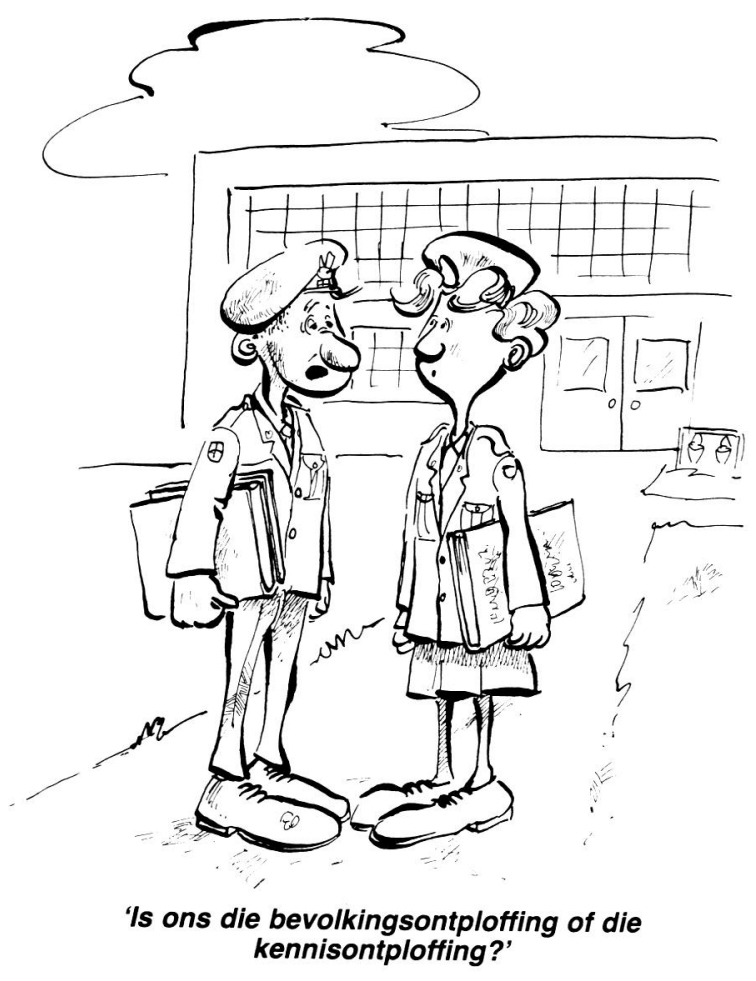

media, relevante leerteorieë en onderwysmetodes $(43: 269,4: 168)$; verhoogde produksie, onderwystekorte, tekorte aan fasiliteite, tyd en geld is 'n probleem - deur middel van Opvoedkundige Tegnologie en die sisteembenadering word beter benutting van bestaande geboue en mannekrag in die hand gewerk, meer relevante kursusse is korter en dra effektief by tot die koste-en tydsfaktor.

Waar spesialisering ('n gevolg van tegnologiese ontwikkeling) die mens reduseer tot instrument (26:393, 394), gaan dit by Opvoedkundige Tegnologie om leer by die mens te verbeter, die mens word dus raakgesien; waar verontmensliking aan die orde van die dag is, propageer, Opvoedkundige Tegnologie die toepassing van tegnieke om individuele onderrig moontlik te maak, byvoorbeeld deur middel van kurrikula in module vorm, geprogrammeerde of rekenaarondersteunde onderrig; waar studente in opstand kom teen onpersoonlikheid en aandring op 'n 'personalized university' (16:326), maak die toepassing van Opvoedkundige Tegnologie die dosent/instrukteur los van sy rol as kennisaflaaier, sodat hy individuele aandag en steun kan gee.

Ook op die gebied waar norme vandag verwater word en algehele vervlakking intree, het Op- voedkundige Tegnologie 'n rol te speel. Deurdat die leerverloop nie meer om die dosent/instrukteur sentreer nie, is hy beskikbaar om sy studente voor te lewe, en waardes aan hulle oor te dra, want 'through clarification of values young people can be helped to make more intelligent, more considered choices.' (15:147)

Waar gelykheid (ook 'n uitvloeisel van die tegnologiese era) vandag gepropageer word, verskaf Opvoedkundige Tegnologie ook die oplossing. 'n Groot verskeidenheid bestaan waaruit die student self (net soos elke ander student) die kursus of module kan kies wat vir hom relevant is; die geleentheid word ook verskaf om verantwoordelikheid vir eie opleiding te aanvaar $(4: 135)$ en teen eie tempo te vorder. Aan die

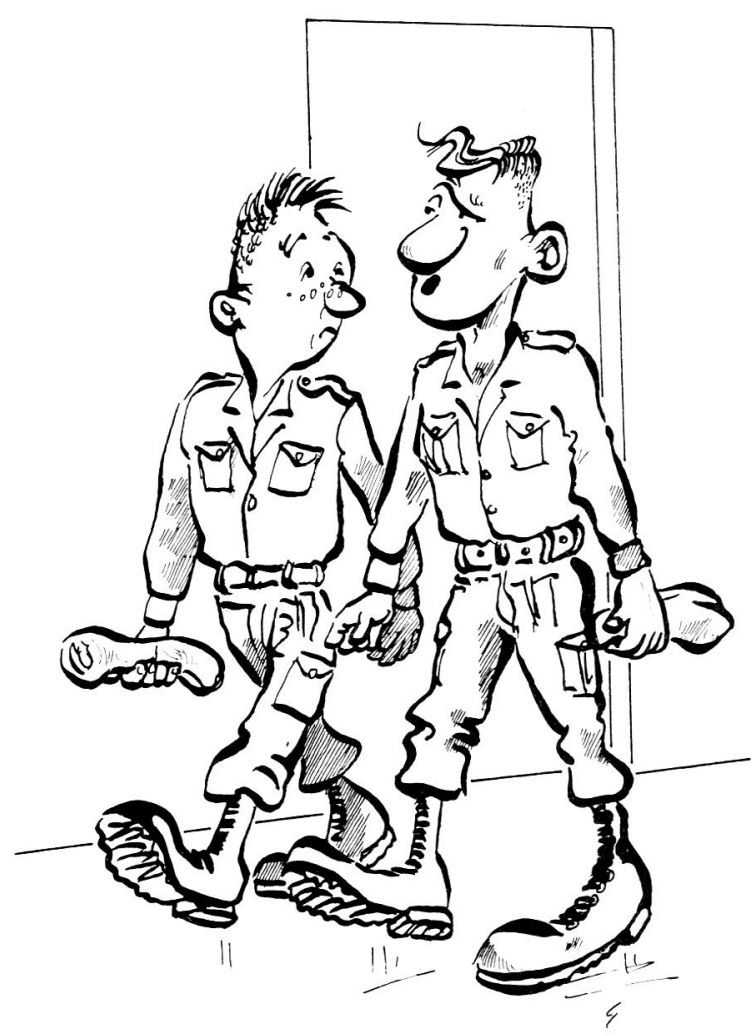

'Ek vorder teen my eie tempo ... teen wie se tempo vorder jy?'

ander kant leer die student, wanneer Opvoedkundige Tegnologie toegepas word, dat afstand wel bestaan, want alhoewel die dosent/instrukteur as gevolg van die snelle ontwikkeling vandag sy outoritêre rol ontneem is ['his words are necessarily wisdom ...'(20:198)], bly hy die spesialis in die leersituasie in dié sin dat hy die doelwitte, die strategie van onderrig, die gebruik van media en die evaluering van resultate bepaal - hy is die bestuurder van opleiding, dit wil sê beplanner, organiseerder, leier en beheerder $(4: 131,12: 138,140)$. 
By die toepassing van Opvoedkundige Tegnologie word die mensdom wat tot volle ontwikkeling moet kom, dus as geheel gesier n Geïntegreerde sisteem maak voorsiening vir die kulturele en opvoedkundige aspirasies van elke individu volgens sy vermoëns, terwyl die behoeftes van die 'fabriek' ook nie uitbly nie - deeglike takkontledings bring mee dat opleiding meer relevant en van hoër kwaliteit is. (27:482)

\section{Invloed van Opvoedkundige Tegnologie opleiding in Militêre verband}

\section{Inleiding}

In die militêre milieu, waar dit gaan om opleiding vir die taak van landsverdediging, speel onderwys en opvoeding as sodanig nie 'n rol nie. Opvoedkundige Tegnologie (en as uitvloeisel daarvan die sisteembenadering) wat taakontledings, duidelike doelwitte afgelei van spesifieke behoeftes en evaluering voorstaan, het hier dus groot moontlikhede, want spesialiste moet opgelei word - 'n weermag waar almal 'n ietsie van alles weet se paraatheid kan bevraagteken word $(4: 171)$

\section{Opvoedkundige Tegnologie in die Britse Vloot}

Die hoofingenieur op die 27000 ton vliegdekskip HMS HERMES het in 1968 voor die probleem te staan gekom dat senior tegnici te min tyd bestee aan onderhoud en instandhouding van die skip omdat te veel van hul tyd in beslag geneem is deur die opleiding van leerlingtegnici. Om die senior tegnici nie voltyds te betrek nie, is besluit op 'n alternatiewe manier van opleiding. $\mathrm{Na}$ 'n taakontleding is duidelike doelwitte en kriteriumtoetse, waarin $90 \%$ as minimum standaard gestel is, opgestel. Die leermateriaal is verskaf in 'n geprogrammeerde teks tesame met 'n oudioband. Oorfone het die enjingeraas in die masjienkamer uitgeskakel en ook verhoed dat studente mekaar steur. Die senior tegnici is slegs betrek vir bekragtiging en evaluering - die instrukteur se betrokkenheid is dus vanaf $100 \%$ tot $20 \%$ gesny, die duur van die kursus is met $50 \%$ verkort, terwyl 'n gemiddelde persentasie van $94 \%$ deur studente bereik is - 'n besliste wins, wat kwaliteit, kwantiteit en tempo betref (3:273-275)

\section{Opvoedkundige Tegnologie in die Britse Lugmag}

In 1968 word die eerste leerpakket ontwikkel. 'A learning package is defined as a collection of resources systematically designed to ensure that the student will achieve the learning objectives' (35:134). Vyf pakkette is ontwikkel vir die teoretiese gedeelte van die 'Mechanical Transport Driver Course' by die Lugmagstasie St Athen. Uit die eerste 100 studente se resultate het geblyk dat die vinnige leerders al vyf pakkette in vyf uur gedoen het, terwyl die stadigste student meer as 70 uur geneem het. Die tyd is egter gemiddeld met 22 uur verkort, terwyl 90\% van die studente met die eerste probeerslag geslaag het (kwaliteit, kwantiteit en tempo) (35:137).

Die RAF beskou 'validation [as] an essential element of a Systems Approach to training, in that it ensures that appropriate action is taken to respond to any changes in job requirements or to rectify any weakness found in the training process' (10:5). Die Britse Departement van Verdediging het in 1979 die term 'evaluering' soos volg gedefinieer: Interne evaluering sou deur skole gedoen word om te bepaal of studente die doelwitte bereik het, terwyl eksterne evaluering die taak van die Departement van verdediging sou wees om te bepaal of die doelwitte verband hou met die taak. Laasgenoemde evaluering het dan ook aan die lig gebring dat 'n sekere kursus vir die opleiding van tegnici hulle in sekere rigtings meer opleiding gee as wat hul taak vereis, terwyl relevante take te min aandag kry (10:13).

\section{Opvoedkundige Tegnologie in die Britse Leër}

Reeds sedert 1950 word baie aandag gegee aan individuele onderrig en sedert 1962 dan ook aan geprogrammeerde onderrig, soveel so dat 'n ondersoek in 1966 aangedui het dat 'n 'technology of education' reeds bestaan en die 'Army School of Instructional Technology' in 1969 gestig word om die beginsels en tegnieke van sisteembenadering verder te ontwikkel (19:242, 243). Die gebruik van die sisteembenadering by die ontwikkeling van kursusse vir die opleiding van die infanteris het selfs sover uitgekring dat opleidingsimplikasies in ag geneem word by die ontwerp van nuwe toerusting $(36: 324,325)$.

Ook die ontwikkeling van 'n kursus vir klerke volgens die sisteembenadering, het vrugte afgewerp. Studente het die kursus in 'n korter tyd as gewoonlik voltooi en ook hoër punte behaal (kwaliteit, kwantiteit, tempo). 'n Probleem is egter ondervind toe hulle weens hul hoë punte op ingewikkelde take waarvoor hulle nie opgelei was nie, aangewend is. Hulle het misluk en die nuwe verkorte kursus moes die blaam dra. (23:27) 


\section{Opvoedkundige Tegnologie in die SA Weermag}

Twee offisiere van die SA Weermag het in Engeland kwalifikasies verwerf, waarna Opvoedkundige Tegnologie en die sisteembenadering geleidelik in die SA Weermag ingevoer is.

In 1978 word 'n kursus vir die opleiding van instrukteurs volgens die sisteembenadering aangebied by die SA Leër se Infanterieskool in Oudtshoorn. Met die nuwe kurrikulum wat op individuele studie gebaseer is, het 1290 studente binne 25 uur die kursus deurloop waarvoor hulle gemiddeld $93,3 \%$ behaal het, terwyl twee instrukteurs 105 uur geneem het om die kontrolegroep van 12 studente op die tradisionele wyse te onderrig. Hul gemiddelde punt was slegs 69,1\% (kwaliteit, kwantiteit, tempo) (13:27-44).

Die SA Weermag se Opleidingsbeleid (SAWO $1 / 2 / 83$ ) waarin 'n sisteembenadering tot opleiding voorgeskryf word, verskyn dan ook in 1979 terwyl 'n opleidingshandleiding in die verband ook die lig sien. Ook die jaar 1983 sal in Opvoedkundige Tegnologie-geledere in die toekoms onthou word vir die aanbieding van 'n loodskursus in Instruksionele Ontwerp vir opleidingsbeplanners.

\section{Opvoedkundige Tegnologie: Algemeen}

Alhoewel die gebruik van oudiovisuele media slegs 'n aspek van Opvoedkundige Tegnologie verteenwoordig en dit nog dikwels oorbeklemtoon word, is dit nodig om die gebruik daarvan in militêre opleiding te noem. Videoprogramme is besonder doeltreffend by die bereiking van gesindheidsdoelwitte. Anders as voorheen tree die besef nou in dat opleidingsprogramme nie soos dokumentêre programme, volskaalse programme hoef te wees nie. 'This role dictates that television should be no different from any other visual aid or piece of equipment in the classroom

. The days of the training cinema have ended' $(23: 28,29)$.

Die rekenaar leen hom weer uitstekend tot die simulering van oorlogs- en ander situasies. Omdat werlike leer aktiwiteit vereis, met ander woorde toepassing van wat geleer is, is sommige militêre opleiding in vredestyd 'n probleem. Simulators soos die Simfire word byvoorbeeld tans in die Britse Leër gebruik om 'n aanduiding te gee of 'n teiken getref is, al dan nie (36:325). Omdat rekenaarondersteunde onderrig tot 'n groot mate gebaseer is op die beginsels van geprogrammeerde onderrig, met sy duidelike doelwitte afgelei van taakontledings, is dit ook in militêre opleiding waardevol.

\section{Toekomsblik}

Wanneer daar oor Opvoedkundige Tegnologie en die sisteembenadering in die toekoms besin word, val veral twee aspekte op: die individualiteit van die mens en die toepassing van dit wat geleer is.

Die tegnologiese ontwikkelinge met sy uitvloeisels soos spesialisering en instrumentalisering laat die vrees van 'n toekomstige robotmens of standaardmens ontstaan. (Toffler (43:257) wys egter juis die teenoorgestelde uit. Die oormaat van verskeidenheid waarmee die mens vandag en nog veel meer in die toekoms te doen sal kry (dink byvoorbeeld aan die verskeidenheid ten opsigte van tandepasta of motors), die tydelikheid van verhoudings (egskeidings) het juis die teenoorgestelde effek, soveel so dat Lasch (26:357) beweer dat die hedendaagse Amerikaner reeds so narcisties ingestel is dat hy nie kinders wil hê nie - hy wil alleen die middelpunt wees. Toffler (43:379) waarsku dan ook: ... the more individualized we are, the more difficult it becomes to find a lover who has precisely matching interests, values, schedules or tastes.'

Ook die onderwys en opleiding sal tot 'n groter mate vir die individu voorsiening moet maak. Individualisering ten opsigte van tempo is nie voldoende nie; ook ten opsigte van inhoude sal verskeidenheid voorsien moet word. 'Unique routing through a curriculum is thus extended to the content and not merely the selection of modules' (28:301). Die sisteembenadering sal dus meer ingestel moet word op die individue (iets wat die rekenaar en sy ontwikkelinge moontlik kan maak); leer sal meer as onderrig beklemtoon moet word en die student sal meer aandag moet kry as die leerpakket (28:295).

'n Terugblik na die definisie van Opvoedkundige Tegnologie, bring dit weer duidelik uit: ' . . toepassing van kennis .... Om Opvoedkundige Tegnologie werklik tot sy reg te laat kom, voorspel Toffler (44:18) dat toekomstige opleidingsprogramme onderbreek sal word deur deelname aan praktiese projekte in die samelewing (toepassing van wat geleer is). Die plek waar opleiding geskied sal dus tot 'n groot mate wegskuif van die tradisionele opleidingsinrigting na die arbeidsituasie of die huis, wat dan ook in lyn is 
met sy voorspelling en die 'electronic cottage' waar studente tuis onderrig sal word (43:204).

\section{Slot}

Opvoedkundige Tegnologie en die sisteembenadering het gekom; dat dit ook vir die toekoms sal bly, word soms betwyfel. Dit het die mens geleer om te leer, maar nou moet hy leer om te lewe, om mens te wees - sal Opvoedkundige Tegnologie dié rol kan vervul? Alle twyfel moet wegval by die aanhoor van die stelling: 'Educational Technology is destined to emerge as the great central humane discipline of the future' $(11: 4)$

* Maj. U. Bouwer, B.A. T.O.D. is $\mathrm{SO}_{2}$ Opvoedkundige Tegnologie by HSP

\section{Bibliografie}

1. Austwick, K. Towards a Technology of Instruction, in The Concept of Educational Technology, ed WK Richmond, London: Wiedenfeld and Nicholson, 1970, pp. 20-22

2. Beishon, J\& Peters, G. 1972. Systems Behaviour. London: Harper \& Row

3. Budget, REB \& Moore, JDS. Audio-programming for Marine Engineering Training in the Royal Navy, in Aspects of Educational Technology III, ed. AP Man and CK Brunstrom, London: Sir Isaac Pitman and Sons Limited, 1969, pp. 272-276

4. Coetzee, JH 1981. Onderwystegnologie in Tydsperspektief (DTO) Pretoria: Universiteit van Suid-Afrika

5. Coggin, PA. 1980. Technology and man. Exeter: A. Wheaton \& Co Ltd.

6. Conradie, PJ \& Du Plessis, PG. 1980. Van Onderrighulpmiddel tot Sisteembenadering. Pretoria: Butterworth

7. Davies, IK. Educational Technology at the cross roads: efficient message design or effective communication, in Aspects of Educational Technology Vol III, ed. J Baggaley, GH Jamieson \& H Marchant, 1975, London: Pitman Publishing, pp. 3-14

8. Davis, RH, Alexander LT \& Yelon, SL. 1974. Learning System Design: an approach to the improvement of instruction. London: McGraw Hill Book.

9. 1956. Die Bybel. Kaapstad: Britse en Buitelandse Bybelgenootskap.

10. Diffey, KS. The external validation of training for ground tradesman in the Royal Air Force, Royal Air Force Education Bulletin, No 20 -Autumn 1982, pp. $5-18$

11. Dunn, W \& Holroyd, C. Aspects of Educational Technology, in The Concept of Educational Technology, ed. WK Richmond, London: Weidenfeld and Nicholson, 1970, pp. 3-4

12. Du Plooy, WJ. 1981. Algemene didaktiek (DTO). Pretoria: Universiteit van Suid-Afrika

13. Eberlein, R. A Systems Model for Training, Militaria vol 9/1, 1979, pp. $27-44$

14. Eberlein, R. 1978. The application of a didactic model to the development of an Instructor Training Curriculum. Pretoria: University of South Africa

15. Eurich, N. Passion versus neutrality, in Learning for tomorrow, ed. A Toffler, New York: Random House Inn, 1974, pp. 147-148

16. Feuer, LS. 1969. The conflict of generations. London: Heineman

17. Friesen, PA. 1971. Designing Instruction. Ottowa: Friesen, Kaye \& Associates Ltd

18. George, GH. Educational Technology, the systems approach and cybernetics, in The Systems Approach to Education and Training, ed. AJ Romiszowski, London, Kogan Page, pp. 22-23
19. Goose, JRT \& Nolan, PT. Twenty years on - the development of Instructional Technology in the British Army, in Aspects of Educational Technology Vol XIII, ed. T Page \& QA Whitlock, London: Kogan Page, 1979 , pp. $242-243$

20. Griffith, PP. Teaching the twenty-first century in a twentieth century high school, in Learning for tomorrow, ed. A. Toffler, New York: Random House Inn, 1974, pp. 197-198

21. Hartley J \& Davies, IK. 1978. Contributions to an Educational Techno/ogy Vol II. London: Kogan Page.

22. Hodge, $P$. The application of general systems theory to secondary education, in The Systems Approach to Education and Training, ed. AJ Romiszowski, London, Kogan Page, 1970, pp. 72-89

23. Hurn, BJ. et al. Innovation in military training: panel session, in Aspects of Educational Technology $V_{0}$ I XIV, ed. R. Winterburn \& L. Evans, London: Kogan Page, 1980, pp. 26-33

24. Konsepopleidingshandleiding vir die SAW. Pretoria: Hoof van die SAW (HSP)

25. Landa, LN. 1976. Instructional regulation and control. New Jersey: Educational Technology Publications, Inc. Englewood Cliffs

26. Lasch, C. 1980. The Culture of Narcissism. Great Britain. ABACUS

27. Mitchell, PD. The professional development of Educational Technology, in Aspects of Educational Technology Vol V. ed. D. Packham et al, Pitman Publishing, 1971, pp. 481-488

28. Mitchell, PD. The concept of individualized instruction in the Microelectronics era, in. Aspects of Educational Technology Vol XIV, ed. R. Winterburn \& L Evans, London: Kogan Page, 1980, pp. 295-301

29. Neil, MW. A systems approach to course planning at the Open University in, The Systems Approach to Education and Training, ed AJ Romiszowshi, London: Kogan Page, 1970, pp. 59-67

30. Neil, MW. An Operational systems approach to research strategy, in Educational Technology, Aspects of Educational Technology III ed. HP Mann \& CK Brunkstrom, London: Sir Isaac Pitman and Sons Limited, 1969, pp. 72-77

31. Neville, C. (ed). The role of Educational Technology in teacher education. Great Britain: Imediaprint

32. Neville, C. Developing strategies for in-service training in Educational Technology, in Aspects of Educational Technology Vol XII, ed D Brooke \& P Race, London: Kogan Page, 1978, pp. 85-93

33. Nunan, E. Educational Technology for the teacher education curriculum, in Aspects of Educational Technology Vol XIII, ed T Page \& QA Whitlock, London: Kogan Page, 1979, pp. 180-185

34. Oberholzer, CK \& Greyling, DJ. 1981. Grondbeginsels van die Onderrig op Tersiêre Vlak. Pretoria: Universiteit van Suid-Afrika

35. O'Hare, B. The design of learning packages in the Royal Air Force in Aspects of Educational Technology Vol VIII, ed J Baggaley et al, London: Kogan Page, 1975, pp. 131-139

36. Phillips, PJ. Training Technology in the Army in the 1980's in Aspects of Educational Technology Vol XIV, ed R Winterburn K L Evans, London: Kogan Page, 1980, pp. 324-327

37. Romiszowski, AJ. (ed) 1970. The Systems Approach to Education and Training. London: Kogan Page

38. Romiszowski, AJ. Systems approaches to education and training, in The Systems Approach to Education and training. ed AJ Romiszowski, London: Kogan Page, 1970, pp. 11-21

39. Rowntree, D. 1974. Educational Technology in Curriculum Development. London: Harper \& Row

40. Seattler, P. 1968. A History of Instructional Technology. New York: McGraw-Hill

41. Slaughter, RE. The response of knowledge industry to society's demand for a more relevant education in Technology and the Curriculum, ed. PWF Witt. USA: Teachers College Press, 1968, pp. 45-52.

42. Stewart, AM Appropriate Educational Technology, in Aspects of Educational Technology Vol XII, ed D Brooke \& P Race, London: Kogan Page, 1978, pp. $159-163$

43. Toffler, A. 1971. Future Shock. London: Pan Books

44. Toffler, A. 1974. Learning for Tomorrow. New York. Random House Inn.

45. Winterburn, R \& Evans, L. 1980. Aspects of Educational Technology Vol $X I V$, London: Kogan Page 